reputation as being one of the most destructive of diseases.

Dysentery, moreover, is one of the great diseases attacking camps, and has been more destructive to armies than powder and shot (Osler). In the Federal service during the Civil War, according to Woodward, there were 259,07 I cases of acute and $28,45^{\mathrm{I}}$ cases of chronic dysentery, and the disease prevailed widely in the South African campaign, in the Frarco-German War of 1870, in the Crimean War, and even before the Battle of Agincourt in $\mathrm{r}_{4} \mathrm{r}$. In the present campaign, too, dysentery has prevailed both in the Western and Eastern seats of warin Gallipoli, for example, in the course of a few months some 78 ,ooo men were invalided on account of sickness, a large proportion of whom suffered from this disease.

The two principal types of dysentery are the amcebic and the bacillary, due respectively to an amcebiform protozoon and to a group of closelyallied bacteria, the dysentery bacilli. Amœbic dysentery or "amœbiasis" is essentially a disease of the subtropical and tropical regions of the globe, and is widespread over the continents of Africa, Asia, and America, and is particularly common in Egypt and India. The causative parasite, the Entamoeba histolytica, is met with as an organism resembling an ordinary amœba in the mucus passed in the acute stage of the disease, and in the liver abscesses which frequently complicate the disease. In this stage it is actively motile, and has a diameter of I/IOoo$\mathbf{I} / 600$ in. It has also an encysted resting stage, found in the intervals between attacks and in latent cases.

Bacillary dysentery, on the other hand, is of world-wide distribution, and is apt to occur in epidemics, thus differing from amobic dysentery. Ogata first isolated and described a dysentery bacillus in Japan; this was followed by researches by Shiga in the same country in 1898 , and by Kruse in Germany. They proved that the bacillus is a specific one, and it was shown later that it was the same bacillus which is now known as the Bacillus dysenteriae of Shiga and Kruse. Later other varieties were isolated by Flexner and by Strong in the Philippines, and by Hiss and Russell (the Y-bacillus).

In England at the present time outbreaks of dysentery chiefly affect asylum populations, and these are almost always caused by the Bacillus dysenteriae of the Flexner type. In one asylum outbreak in England and in an epidemic in Scotland Shiga's bacillus has been isolated.

Almost all the cases of dysentery returning from Gallipoli are of the bacillary variety, and the experience of Ledingham, Penfold, and Woodcock ${ }^{1}$ appears to show that the infection is chiefly with the Shiga bacillus, while in a smaller number the Flexner bacillus is present. From the eastern Mediterranean a few cases of infection with the Entamoeba histolytica have been reported. Among the French in the

\footnotetext{
1 See Brit. Med. Journ., November r3, 1915, p. 704

No. 2406, VOL. 96]
}

Argonne the large majority of the numerous cases occurring there are due to the $\mathrm{Y}$-bacillus of Hiss and Russell. In the Germany army on the west front cases due to the Flexner bacillus are reported, while among the Austrians infection with the Shiga bacillus is met with.

In the treatment of amœbic dysentery emetine, an alkaloid of ipecacuanha, is practically a specific, and for the bacillary form anti-dysentery serum is very successful.

Outbreaks of dysentery in armies raise many important problems for the sanitarian. The disease is partly water-borne, though, of course, there is considerable opportunity for direct contamination of food and person in camp and trench life. The intestinal evacuations of cases contain vast numbers of dysentery bacilli and, unless disinfected, infect the locality, particularly the trenches and their neighbourhood, where the men are attacked before removal to hospital, while infection may be spread far and wide owing to the fact that the bacillus does not necessarily disappear from the patient with the onset of convalescence, but may remain in the body for a long time after cessation of symptoms, so that the "carrier" state becomes established. It would probably be desirable to regard a case as possibly infective for a period of three months after the termination of the attack, but the exigencies of war may prevent such a course. Bacteriological examination ought also to be carried out so far as possible to determine when an individual has ceased to be a "carrier."

At present a high standard of general and personal hygiene is the best preventive of the disease. Attempts have been made to introduce preventive inoculation against bacillary dysentery, but with what success is not yet known.

R. T. HEWLETT.

\section{OILS AND FATS AS WAR SUPPLIES.}

THE discussion in the House of Commons last week, on the export of oils to neutral countries bordering on Germany dealt with a matter on which scientific knowledge might have been brought to bear with great national advantage.

There is no doubt that fats are the one material that a country situated in northern Europe must procure from without; indeed, the price of oils current in Germany affords complete testimony of the accuracy of this statement. Fats are of value for two purposes: first, as an altogether indispensable article of food, and, secondly, as a source of glycerine, which is converted into nitroglycerine and becomes an ingredient of all propellent explosives. Apart from tallow, and perhaps some small amount of linseed, Germany produces no other fat, and her stocks could have lasted but a limited time only. The deficiency has been made up by imports from tropical lands through neutral countries, which, so long as we have control of the seas, can only be obtained by favour of Great Britain.

One by one restrictions have been placed on 
the export from British ports of the more obvious fatty materials used as food, but the fact that oils contain glycerine seems to have been largely overlooked, though the belated announcement made last July by Sir F. E. Smith, then SolicitorGeneral, that "it had recently (!) been discovered that glycerine could be made from lard" must not be forgotten. Some oils or oil-yielding materials are still being allowed to go to neutral countries; for example, linseed or linseed oil, and palm kernels, have been exported to Holland; whale oil is being largely shipped to Norway. Linseed oil, which was formerly only of use as a drying oil, can now be saturated with hydrogen and converted into a hard, white fat suitable for use in margarine. The same applies to whale oil ; and there is a very large factory in Norway engaged in this work.

It was claimed in the debate that it is necessary to send these oils to Holland in order that cheap margarine may be returned to Britain. If this be so, the question arises whether all that is possible has been done to protect and foster our own margarine industry, and if the English output of margarine is at its maximum. The answer is probably in the negative-the English maker is short of labour and he is being undersold by his foreign rivals, who are making huge profits in the German markets.

\section{PROF. C. R. ZEILLER.}

CHARLES RENÉ ZEILLER, whose death after a long illness was announced from Paris a few days ago, was a member of the Institute, chief engineer of mines, and professor of palæobotany in the National School of Mines. Despite the heavy claims of official duties, Zeiller devoted himself to palæobotanical investigation for nearly forty years. His earlier papers dealt with the Carboniferous and Permian plants of France, and the most important of these is the volume, published in 1878 , on the plants of the French Coal Measures. The beautifully illustrated and scholarly monographs of Palæozoic floras, including those of Valenciennes, Commentry (in collaboration with the late $M$. Renault), Autun, Brive, Creusot, and Blanzy, are models of scientific exposition and thorough workmanship. The two volumes on the Rhætic flora of Tonkin, published in 1903, are the most important of his contributions to the botany of the earlier phase of the Mesozoic era. He also wrote several papers on later Mesozoic plants from different parts of the world, and added considerably to our knowledge of the Permo-Carboniferous floras of South Africa, Brazil, and India, both by his description of new types and his masterly treatment of the wider problems presented by the socalled Glossopteris flora of the southern hemisphere.

Though mainly concerned with impressions of Palæozoic and Mesozoic plants, Zeiller's researches into the structure of the Palæozoic fern Psaronius and, more recently, his work on the NO. 2406, VOL. 96] anatomy of Lepidostrobus bear witness to his skill as a morphologist. For many years he contributed to the Revue Générale de Botanique a critical and comprehensive survey of recent palæobotanical literature; the enormous amount of work represented by these articles illustrates his untiring energy and his unselfish devotion to the subject which he loved. In 1905 Zeiller was elected a foreign member of the Linnean Society, and in 1909 he received the same recognition from the Geological Society of London. In the latter year he visited England for the first time to attend the Darwin celebration at Cambridge, and was one of the distinguished band of foreigners upon whom the University conferred honorary degrees.

Zeiller had a remarkably wide and accurate knowledge of his subject. $\mathrm{He}$ was much more than a learned systematist; while scrupulously accurate in his exceptionally lucid descriptions, he always took a broad view. He had the power of synthesis as well as that of analysis. He never wrote too much, and all that he did bore testimony to his courtesy, singleness of purpose, and modesty. Zeiller was a man of simple dignity and great personal charm; his death is a severe blow to a department of knowledge. which claims a comparatively small number of students. He leaves a rich legacy of scientific achievement to a younger generation, and to his friends the stimulating memory of a noble character.

A. C. Seward.

\section{PROF. F. R. BARRELL}

RY the sudden death, on December 2, of Prof. F. R. Barrell, at fifty-five years of age, the University of Bristol has lost one of the senior members of its staff. After graduating at Cambridge (Math. Trip., I882, I 4 th wrangler; Nat. Sci. Trip., I883) and in London University (B.Sc., I884), he was for two years lecturer in Hammond Electrical College and for five years instructor in natural science in the Britannia. In $r 890$ he was appointed lecturer in mathematics in University College, Bristol, and was given the status of professor in 1893 . When the University College was merged in the University of Bristol he was elected Dean of the Faculty of Science, and was one of the representatives of Senate on Council. At the time of his death he was Dean of the Arts Board, and again a member of Council.

Sound, especially in fundamental conceptions, rather than brilliant as a mathematician, his main interests lay in the application of mathematics to practical problems in physics and in methods of teaching, with constant insistence on the importance of a securer basis clearly and adequately grasped. His work bore fruit in its influence on those whom he trained. In his earlier days he wrote on electrical problems ("Electricity and Magnetism," I894), and later on "Elementary Geometry" (I904). He was a pioneer in the localisation of a needle or bullet by 